\title{
Destination Ethiopia: Heritage sites for tourism development
}

In 1963, the UN Conference for International Travel and Tourism in Rome issued Recommendations on International Travel \& Tourism, declaring tourism to be "a vital element in the framework of the United Nations Development Decade". ${ }^{48}$ In the subsequent campaign, the governments of developing countries were strongly encouraged to prioritise the tourism sector in their development plans. ${ }^{49}$ The UN International Tourist year in 1967 provided a strong visual outcome of this programme, in addition to the 1966 UN ECOSOC policy, "inviting the international financing agencies to provide the developing countries [...] assistance for the promotion of tourism." 50 At the same time, the United Nations Conference on Trade and Development (UNCTAD) released a recommendation "urging [...] particularly the developing countries to promote tourism, which makes a vital contribution to their economic growth." 51

\section{Tourism planning in Ethiopia}

The widespread enthusiastic forecasts regarding the economic potential of tourism development for African countries, produced during the 1960s, were received with open ears in Ethiopia. Modern tourism in Ethiopia started with the national airline, Ethiopian Airlines (EAL). Founded in 1946 in partnership with the private US-corporation Trans World Airlines (TWA), EAL was crucial for national integration and economic development in Ethiopia, and a big asset in rebuilding the image of the country. The airline was a very successful enterprise, earning profit soon after its founding, and gaining a reputation for its services. Addis Ababa became a relevant African hub for air travel, which in turn strengthened Ethiopia's power and relevance on an inter-African as well as an international scale. Establishing domestic air trade routes fast forwarded Ethiopian national integra-

48 United Nations Conference on International Travel and Tourism, Recommendations on International Travel and Tourism (Geneva: United Nations, 1964), 17.

49 Marie-Françoise Lanfant, "Tourism in the Process of Internationalization", International Social Science Journal 32, no. 1 (1980): 15.

50 UNESCO General Conference, "Resolutions of the Fourteenth Session, 1966” (1966), 62.

51 Ibid., 63.

Ә OpenAccess. ( 2021 Marie Huber, published by De Gruyter. (cc)BY BY This work is licensed under the Creative Commons Attribution 4.0 International. https://doi.org/10.1515/9783110681017-004 
tion, because it increased mobility and connections between existing urban centres, and the capital. ${ }^{52}$

As early as 1950, EAL began to promote package tours within EAL's domestic flight routes to the international audience residing in Addis Ababa, which was composed of diplomats, foreign experts and their families..$^{53}$ As most of these expatriate residents were remunerated from external sources, and this particular kind of domestic tourism presented a means to absorb a part of this foreign exchange into the Ethiopian national economy, from the 1960s Ethiopian airlines advertisement started targeting the North-Atlantic market. ${ }^{54}$

In the context of tourism, experts argued for investment in conservation to increase the destination value of heritage sites. Consequently, in Ethiopia, like in most African countries, national parks and monuments were part of the tourism commission's responsibility, and the conservation and general investment in the sites of cultural and natural heritage turned into aspects of development planning. In the second five-year development plan of 1962, "the pleasant climate, mineral hot springs, natural beauty, historical monuments and hunting possibilities [...]" were seen to "constitute untapped sources of the national wealth and offer great possibilities for the development of planned tourism." 55 The plan foresaw selected government investment in building hotels and other accommodation, and opening tourist-information centres abroad. Further plans included the restoration works on historical monuments, and the development of one selected site with additional facilities as a showcase-project. As a side note, the establishment of game-reserves and national parks as tourist attractions was included in the "Fishing \& Forestry" section of the plan. ${ }^{56}$

With the establishment of the Ethiopian Tourism Organisation (ETO) in 1964, the government acknowledged the increasingly central role of tourism for economic growth. The ETO was responsible for several aspects related to tourism development in order to systematically address existing problems. In its duty-free

52 Ethiopian Airlines, Bringing Africa Together (Addis Ababa: Ethiopian Airlines, 1989), 100 103; Theodore Geiger, TWA's Service to Ethiopia (Washington, DC: National Planning Association, 1959), 62-71.

53 Travel News, no date, in: NALE 1.2.12.01, Ethiopian Airlines.

54 I argue to understand this as a strategy of the Ethiopian government to monetise Addis Ababa's role as a diplomatic and international hub, through the luxury hotels, the high import tax on luxury goods and the duty-free shops of the ETO. Vojislav Popovic, Tourism in Eastern Africa (München: Weltforum, 1972), 91. Several brochures in: NALE 1.2.12.01, Ethiopian Airlines; Addis Ababa became the most important African hub for air travel, Geiger, TWA's Service, 71.

55 Imperial Ethiopian Government, Second Five Year Development Plan, 1963-1976 (Addis Ababa: Berhanenna Selam Printing Press, 1962), 240.

56 Ibid., 150. 
shops, "King Solomon's Mines", they sold "tourist art" handicraft articles in addition to regular duty-free items such as liquor and tobacco. These articles resembled traditional cultural items and were specifically designed and produced in workshops operated by the ETO. This created additional income, enabling the ETO to expand and operate tours and car-hires. The ETO and EAL also operated a number of tourist-hotels, meaning hotels suitable to host international travellers and tourists. Most importantly, the ETO developed a marketing strategy as well as extensive tourism promotion material. ${ }^{57}$

Tourism was stated in the third five-year development plan of 1968 as the key to bettering the country's economic well-being. With neighbouring countries such as Kenya held up as positive examples, "it was envisaged that much more attention will be given to the possibilities of tourism as a potential source of foreign currency than has been possible in the past." ${ }^{58}$ A more integrated, inter-sectoral approach turned tourism in a government responsibility and the new, coordinated development plan for tourism defined very clearly the central role of the government in the tourist industry.

A decade of more extensive tourism planning followed these assessments. In the 1969 a grand Ethiopian Tourist Development Plan was commissioned from an Italian planning firm. The high expectations for tourism were detailed out in this plan. In just eight years the investment planned for tourism was believed to have returned equivalent benefits in full, in addition turning a capital investment of 92 million Ethiopian dollars into a total income of 450 million Ethiopian dollars within thirteen years, with indirect benefits believed to be four times as high. ${ }^{59}$

To reach these goals, great investment in tourism was needed. "The lack of necessary infrastructure, the lack of special air fares making it possible to include Ethiopia in East African and all-African tours, the lack of travel promotion in overseas markets"60 all presented difficulties that had to be overcome. The Ethiopian government reached out for international assistance for tourism planning. The International Bank for Reconstruction and Development (IBRD) conducted an independent assessment and stated that "tourism would be the second most important source of foreign trade for Ethiopia (following the export of coffee)". The Bank was convinced of tourism as a crucial factor for economic

57 Ayalew Sisay, Historical Development of Travel and Tourism in Ethiopia (Addis Ababa: the author, 2009), 92; Tafesse Habte Selassie, “Tourism”, in Encyclopaedia Aethiopica, ed. Siegbert Uhlig (Wiesbaden: Harrassowitz, 2010), 973.

58 Letter from Belai Abbai to Malcolm Adiseshiah, 4.1.1968, UNESCO X 07.21 (63) pt. iv.

59 Ianus. Organizzazione per gli studi e le ricerche di economia applicata S. p. A., Ethiopian Tourist Development Plan (Milan: Franco Angeli, 1969), 12.

60 Popovic, Tourism in Eastern Africa, 97. 
development, as it seemed capable of considerable expansion. ${ }^{61}$ Subsequently, a World Bank loan for the development of tourism-including the preservation of sites and monuments-was approved. ${ }^{62}$

At least in the funding proposals and consultants' reports, tourism was played up as a cure-all of Ethiopia's development problems. Not only would it earn the revenue necessary for further economic development, it would also initiate key infrastructure projects such as transportation and electricity that had failed to be realised in their own right.

\section{UN-sponsored tourism planning for developing countries in the 1960s}

The roots for tourism as it became an item on the agenda of international development programmes go back to the European, and more particularly British, tradition of the nobility touring other countries as part of their education, also known as the Grand Tour. The transformation of work-life-organisation that took place with the industrialisation in European societies brought a new availability of leisure time, which was often combined with a desire to travel for recreational purposes. The introduction and elaboration of paid holidays since the 1920s made way for the concept of leisure time that could be spent travelling elsewhere. This became feasible for a significantly large number of workers, a contrast to previous times where travelling for recuperation and education had remained a privilege of the upper and middle classes. The ever-growing number of salaried workers that were entitled to paid holidays contributed to the growing volume of travel that had begun to be classified as touristic. The stabilised political situation and the rapid economic growth after the end of the Second World War in Western Europe, Australasia and North America and the large-scale economic, social and technological changes occurring alongside resulted in a tremendous rising of tourist numbers and a booming tourism sector. The extent of available investment eased the expansion of necessary infrastructure and the increase in disposable income caused a significant yearly growth of the sector. Finally, the technological innovations of motorisation, the expansion of railway and road infrastructure and the introduction of air travel made mass transportation easier, less time-consuming and affordable. ${ }^{63}$ In the contemporary understanding of the 1960s, tourism was distinguished as a decidedly modern,

61 Project report, no date, in UNESCO 069:72 (63) UNDP pt. vi.

62 Letter from M. Jiminez to Bruce Stedman, 13.3.74, in UNESCO 069:72 (63) UNDP pt. i.

63 Manish Ratti, History and Geography of Tourism (New Delhi: Rajat Publications, 2007), 22-24. 
European phenomenon, not least because only a certain percentage of the world's population was able to engage in such travel. In tourism development planning, non-Western and pre-modern forms of travel, such as pilgrimage, were not included. ${ }^{64}$ For tourism planners, the world was clearly divided into those who travel and those who are travelled to, the Western and Non-Western countries, and domestic tourism was something that did not exist in developing countries. ${ }^{65}$

The growth of tourism eventually turned it into a powerful factor in economic development, quickly acquiring importance in many national economies, increasing the business of tour operators and all branches of the hospitality industry, be they accommodation, food or entertainment. International organisations and networks were formed, the most important of these being the International Union of Travel Organisations (IUOTO), established in 1946. IUOTO concerned themselves with issues relating to travel conditions, especially visa and passport regulations, but also joint regional advertising and the definition of standards. To strengthen its policymaking capacities and following a majority vote backed largely by developing countries, in 1974 IUOTO was transformed into the UN World Tourism Organisation (UNWTO) and elevated to the ranks of a UN special agency, excluding the private sector members. ${ }^{66}$ The UNWTO, in undertaking more targeted attempts to centralise tourism policies internationally, brought forward important global tourism policies like the 1980 Manila declaration and the 1982 Acapulco Document. ${ }^{67}$

Most noteworthy about the work of these international organisations is the fact that the recommendations and policies explicitly stated tourism to be a critical factor for challenging global inequality. In the official resolutions and statements, tourism was explained as a mechanism to redistribute the resources of rich societies to poor ones, contributing to the restructuring of the international economic system towards the New International Economic Order. Among econ-

64 Dennison Nash, “Tourism as a Form of Imperialism”, in Hosts and Guests: The Anthropology of Tourism, ed. Valene L. Smith, 2nd ed. (Philadelphia: University of Pennsylvania Press, 2012), 33-52, https://doi.org/10.9783/9780812208016.37.

65 Krishna B. Ghimire, ed., The Native Tourist: Mass Tourism within Developing Countries (London; New York: Earthscan, 2001), 8-11.

66 World Tourism Organisation, "Creation of the Inter-Governmental World Tourism Organization”, ATR Annals of Tourism Research 2, no. 5 (1975): 237-45; United Nations Conference on International Travel and Tourism, Recommendations.

67 "Manila Declaration on World Tourism", UNWTO Declarations 6, no. 4 (30 October 1980): 1-4, https://doi.org/10.18111/unwtodeclarations.1980.6.4.1; United Nations World Tourism Organization, “Acapulco Document”, August 1982, http://www.e-unwto.org/doi/pdf/10.18111/un wtodeclarations.1982.8.4.1. 
omists and other international development experts, tourism held a particular value for developing countries to materialise economic potential and surpass their "under-development". ${ }^{68}$ The biggest advantage of tourism, in their opinion, was that it was a non-threatening export industry, offering a product that was not in any competition with the domestic industries of the Global North.

Mass-tourism on a global scale was, despite the exploding numbers of tourist arrivals during the 1960s, largely confined to the Western hemisphere. The vast majority of arrivals were registered in Europe and Northern America, meaning it was Europeans traveling inside of Europe or American or Canadian citizens traveling inside Northern America. A smaller number of tourists from these Western countries travelled to non-Western countries, generally neighbouring ones. Tourism business did not yet exist in most developing countries, yet, this favourable development was readily projected onto regions rich in potential destinations all over the world, such as South East Asia, Latin America and East Africa by planners and politicians. The increase in global revenue from foreign tourism by $75 \%$ between 1958 and 1963 seemed to justify the build-up of tourism as the universal remedy for countries lacking a developed industrial sector or natural resources ready to exploit. ${ }^{69}$ Many planners, entrepreneurs and politicians predicted rising numbers of tourists to developing countries, resulting in a steady growth of tourism, a growth that would divert cash flows from the prosperous countries of said tourists straight into the national economies of their destinations. $^{70}$

\section{Surveying Ethiopia's natural and cultural heritage}

With economic development becoming the ultima ratio for all sizeable amounts of funding within the UN system, tourism was a welcome opportunity to connect a chronically under-financed activity, the conservation of cultural and natural sites, to existing cashflows. ${ }^{71}$ It was a generally accepted fact that there was a lack of funds for conservation in developing countries, and that tourism could serve as a potential source for these funds. Some experts went even further, stat-

68 Emanuel de Kadt, World Bank, and UNESCO, eds., Tourism: Passport to Development? Perspectives on the Social and Cultural Effects of Tourism in Developing Countries (Oxford; New York: Oxford University Press, 1979), xiii; Lanfant, “Tourism”, 19.

69 N.N., “1967 - International Tourist Year”, UNESCO Courier 19, no. 12 (1966): 6.

70 Popovic, Tourism in Eastern Africa, 188.

71 This is the general tone of the numerous reports and papers, illustrating the cultural tourism discourse in UNESCO, in: UNESCO 069:72:380.8 A 193. 
ing that the conservation of monuments and wildlife presented the only major potential for tourism in most developing countries, as people would not travel so far simply to spend leisure time at a beach. Cultural and natural heritage, in most developing countries, was considered an attraction at the core of a destination.

International nature conservation experts agreed that African fauna, flora and habitat was the most urgent conservation problem of the time. ${ }^{72}$ In 1960, Julian Huxley, former Director General of UNESCO, African wildlife biologist and prominent spokesperson for eugenics and geo-engineering, embarked on a mission for UNESCO, "to investigate the problem" of conservation and wildlife in East and Central Africa. ${ }^{73}$ After touring the national parks of Rhodesia, and Nyasaland, Tanganyika, Kenya, Uganda and Zanzibar, Portuguese East Africa (Mozambique) and eastern Congo and South Africa he wrote: "The situation can still be saved provided that the conservationists can induce African governments and the African public to understand and follow an ecological approach". ${ }^{4}$

After this first mission, international conservation experts sought for more effective ways to interest African governments in natural and wildlife conservation. A special project for "Conservation of Nature and Natural Resources in modern African States" was conducted by IUCN and FAO, with the intention of assisting interested countries in establishing wildlife conservation strategies. The framework of this "African Special Project" went back to an IUCN decision in 1960, after which two designated experts started to travel and promote a number of Eastern African countries. The FAO/IUCN African Special Project encompassed two approaches to natural protection-conservation as well as resource mobilisation. At the 1961 conference in the context of the special project, European and US-American wildlife experts and African politicians concluded that only through the economic incentive would natural conservation be successful in African societies. In his speech, the Tanganyikan Minister of Lands and Surveys, T.S. Tewa, explained:

It must, however, be said that the almost mystical and romantic regard for wild animals which some people have, has often puzzled the peoples of Africa. To many Africans, the

72 Gerald G. Watterson, ed., Conservation of Nature and Natural Resources in Modern African States: Report of a Symposium Organized by CCTA and IUCN and Held under the Auspices of FAO and UNESCO at Arusha, Tanganyika, September 1961 (Morges: IUCN, 1963), 3, https://por tals.iucn.org/library/sites/library/files/documents/NS-001.pdf.

73 Julian Huxley, "The Conservation of Wild Life and Natural Habitats in Central and East Africa: Report on a Mission Accomplished for UNESCO, July-September 1960 [Serial No. NS.61/ D.31/A]" (Paris: UNESCO, 1961).

74 Ibid., 12. 
elephant is a dangerous agricultural pest, the lion a savage killer of men and stock, and the wildebeest an unwelcome competitor for scarce grazing. Residents in Africa expect protection from damage by game and they expect to see that where human interests and those of animals conflict, the interests of animals are allowed to prevail only in carefully chosen and restricted areas. But if the mass of my countrymen are to be enlisted in the ranks of conservationists, they will need to be convinced not only that the animals in these restricted areas, that is the Parks and Reserves, can be more use to them alive than dead, but that the money necessary to preserve them would not be better spent on more schools and doctors. In other words, they will expect us to see that what they are told is "their heritage", however valuable it may be as a cultural asset, can still be made to earn its keep. Can this be done? I believe it can-through tourism. ${ }^{75}$

After the experts had made their initial tour, where the idea was introduced to the new African national governments, the Ethiopian government proved particularly receptive to the concept. ${ }^{76}$ Ethiopia was included in Julian Huxley's 1960 report, together with some other African territories of which he delivered an assessment by proxy, based on reports of IUCN observer G.G. Watterson. In this brief section, the value of Ethiopian wildlife was measured exclusively in terms of interest and attraction for a Western audience: "Ethiopia possesses fine mountain scenery, wonderful canyons, large upland areas with a cool climate, and many sites of great historical and archaeological interest. There is still a fair abundance of interesting wild animals, especially in the south of the country, but it is being seriously and rapidly reduced by illicit killing." In 1963 Akalework Habtewold, Ethiopian Minister for Agriculture, submitted a request to UNESCO, asking for assistance for the development of national parks and the protection of wildlife in Ethiopia. In his address to the DG and the General Assembly of UNESCO, Akalework Habtewold stated: "It is our wish to manage and develop national parks and wildlife reserves in such a way as to secure the preservation of their flora and fauna, provide centres of biological and ecological research, and contribute to the growth of the national economy, especially through the development of tourism and game cropping." 77

75 T.S. Tewa, "The Value of the Tourist Industry in the Conservation of Natural Resources in Tanganyika”, in Conservation of Nature and Natural Resources in Modern African States - Report of a Symposium Organized by CCTA and IUCN and Held under the Auspices of FAO and UNESCO at Arusha, Tanganyika, September 1961, ed. Gerald G. Watterson (Morges: IUCN, 1963), 337, https://portals.iucn.org/library/sites/library/files/documents/NS-001.pdf.

76 T. Riney and P. Hill, “FAO/IUCN African Special Project: Interim Report on Ethiopia” (Rome: FAO, 1963), 1-2.

77 Julian Huxley et al., "The Conservation of Nature and Natural Resources in Ethiopia [Serial No. NS/NR/47]" (Paris: UNESCO, 1963), 6. 
The request was met positively: "Fully conscious of the scientific, cultural, educational social and economic importance of the natural habits, of the wildlife, constituted by a large variety of species, some of which are endemic, of the remarkable landscapes and archaeological sites of Ethiopia which represent an inheritance of universal interest the DG decided to support the request."78

In 1963, a further UNESCO mission was dispatched to Ethiopia, composed of senior experts from European and American institutions of wildlife conservation. It was headed by Julian Huxley, with the other members of the mission L. Swift, former Director of the Division of Wildlife Management, U.S. Department of Agriculture, Dr. Barton Worthington, Deputy-DG of the United States-based charity organisation Nature Conservancy, and Professor Theodore Monod of the Musée national d'histoire naturelle in Paris. Julian Huxley had been on a mission concerned with "The Conservation of Wild Life and Natural Habitats in Central and East Africa" in 1961, leading him to include second hand information about the relevance of Ethiopian wildlife and scenery, prompting a recommendation to consign a mission to further investigate on the matter. ${ }^{79}$

The mission's main concern was, per definition of the request, wildlife, but corresponding with the DG's feedback, the final report contained remarks on cultural monuments as well. ${ }^{80}$ This indicates that all actors involved understood national heritage as a portfolio of sites, and in a way that it would inherently encompass both natural and cultural sites. During the short period of two weeks, the experts produced little more than very general recommendations, emphasising the lack of conventional, functional government institutions required to practice conservation in the first place. The report also contained, however, a suggested selection of sites, namely the "Managasha National Park", "Matahara Proposed National Park in Awash”, “Abijatta Lake Proposed National Park”, a "Proposed National Park in the Rift Valley" and "A Scenic National Park at the Source of the Nile. ${ }^{81}$ Another mission from UNESCO embarked to Ethiopia, during 1964/1965, carried out by Leslie Brown, former Director of Agriculture in Kenya, and Major Ian Grimwood, former Chief Game Warden of Kenya, in order to "provide assistance to the Ethiopian Government in the field of conservation of nature and natural resources, their restoration and enrichment." The consultants themselves described their missions as leading to positive results,

78 Ibid., 6.

79 Huxley, "The Conservation of Wild Life", x.

80 John H. Blower, "Wildlife Conservation and National Parks: Ethiopia - (Mission) September 1965-September 1969 [Serial No. 2351/RMS.RS/SCE]” (Paris: UNESCO, 1971), 6; Huxley et al., "The Conservation of Nature", 9-16.

81 Huxley et al., "The Conservation of Nature”, 32. 
highlighting specifically the establishment of a government authority for wildlife, the Ethiopian Wildlife Conservation Organisation (EWCO). Remarkably, as with Huxley et al., Grimwood and Brown referred in their reports to the proposal for the establishment of a conservation board in charge not only of wildlife but also "archaeological resources". ${ }^{82}$ The proposal went as far as to claim that only tourism would provide the justification needed for the board to successfully carry out conservation:

The present wildlife potential of Ethiopia is insufficient to support a large tourist industry on its own, in face of competition from nearby East African countries where game is more plentiful and more easily seen. The richness of Ethiopia's fauna lies more in its uniqueness than in the spectacular number of variety of animals to be seen, which tends to make it of less interest to the general public. The country has, however, historical sites and antiquities such as are to be found nowhere else in Africa south of the Sahara. It also has some of the grandest scenery in the world. Only by the inclusion of such attractions into the first major tourist circuits does it seem likely that a large enough flow of visitors can be created to provide the Board with the means to carry out its present primary task of saving some of the country's rarer animals. ${ }^{83}$

The idea that African natural heritage on the one hand needed protection from African people and on the other hand was a promising economic resource combined racist and paternalistic thinking and shaped the tourism planning in many newly independent nation states in Africa. The parallels to the international programmes for the conservation of built heritage are striking: tourism appeared as an issue among international heritage experts from the 1950s on, and came with a distinct economic rationale. It was mentioned as early as 1949 as one of the "problems of common interest to organisations concerned with [...] sites and monuments of art and history" in a meeting of experts, taking place at UNESCO. ${ }^{84}$ Tourism, and more specifically the economic potential of tourism as regards historic sites, was a factor that arose from the international perspective on historic monuments and the creation of the idea of a global heritage landscape. Monuments, sites and nature were already features of tourist destinations in Europe, so the principle was transferred to the new international scope, and

82 Blower, "Wildlife Conservation", 6; Ian R. Grimwood, "Conservation of Natural Resources: Ethiopia - (Mission) November 1964-February 1965 [Serial No. WS/0865.66 REV.AVS]” (Paris: UNESCO, 1965); Leslie H. Brown, "Conservation of Nature and Natural Resources: Ethiopia (Mission) 30 December 1964 to 1 April 1965; Report [Serial No. WS/0865.192/AVS]” (Paris: UNESCO, 1965).

83 Brown, "Conservation of Nature", 2.

84 Unesdoc, Georges Henri Rivière, "Meeting of Experts on Sites and Monuments of Art and History; Paris; 1949”. 
the idea of economic profit from tourism to benefit the conservation of monuments was expressed in proposals, such as the 1951 plan to adopt an international convention that would institute a special tourist tax for the preservation of monuments and museums. ${ }^{85}$

The intertwining of the growing relevance of tourism and the development paradigm turned cultural and natural heritage into an economic resource, and provided a unique chance for UNESCO to enter the development playing field. By 1960, while mainly involved in educational efforts of technical assistance, UNESCO's division for cultural heritage saw itself at the intersection of both of the main arguments for tourism: the idea that tourism could promote international understanding and education, as well as the requirement to develop cultural heritage as a resource in a responsible manner, and felt obliged to advance both causes. ${ }^{86}$ Tourism, for UNESCO, promised to be a highly effective pedagogic tool, aiming to present the monuments as teaching institutions for history. UNESCO initially saw itself as only concerned with tourism in cases where tourism development projects carried a cultural component. ${ }^{87}$ Its contribution to tourism aimed to counterbalance the purely economic interest in tourism research and planning with educational, cultural and scientific impulses.

In 1962, tourism was stated to be an important means of action in the first plan of proposed action for UNESCO's international campaign for monuments. ${ }^{88}$ UNESCO's division of museums and monuments commissioned a study to evaluate tourism statistics, in order to develop a concept for an "international fund for monuments." 89 These concerns were motivated by an acute shortage of funds for the aspirations of international conservation experts. They turned to a more strategic planning, considering what would produce the most promising positive public response.

In the context of the first UN Development Decade, the conservation of natural and cultural heritage and the promotion of tourism and the concerns of development were combined into a momentous plan called "Associating the preservation of cultural property with the development of tourism”:

85 Ibid., Preliminary Study on the advisability of international measures for the institution of a special tourist tax, submitted to Executive Board, Paris, 12.1.1951.

86 UNESCO, 72/EX/Decisions, Art. 10, 1966.

87 Letter from J. Hardouin, no date, in: UNESCO 069:72:380.8 A 193.

88 Template letter from DG René Maheu to ministers of member states, 31.7.1962, in: UNESCO 069:72 A14.

89 Letter from Giorgio Rosi to Conrad André Beerli, 2.8.62, in: UNESCO 069:72 A14. 
How can money be raised for the restoration of protection of the world's heritage of monuments? A new Unesco [sic] plan offers an answer-turn the monuments into paying affairs. Unesco [...] suggests, that countries should turn their cultural assets into economic ones by giving priority to monuments in programmes of tourist development. [...] Unesco is studying how funds for such projects can be obtained from regional and international organisations and through the U.N. Development Programme, since the tourist industry is seen as a key factor in economic development. ${ }^{90}$

In practice this resulted in a number of expert missions concerned with tourism, based on requests from developing countries. Between 1966 and 1980 alone, missions were carried out to the following twenty-three countries: Algeria, Bangladesh, Bolivia, Brazil, Bulgaria, Cambodia, Cyprus, Ecuador, Ethiopia, India, Indonesia (Bali), Iran, Libya, Malta, Mongolia, Nepal, Nicaragua, Kenya, Pakistan, Peru, the Dominican Republic, the United Arab Republic and Thailand. ${ }^{91}$ The tourism development missions between 1966 and 1980 were all very similar in terms of the initial task outlined, and consisted of assisting the government in developing recommendations on the establishment of tourism as a source of economic development, and in giving directions for developing existing resources of natural or cultural sites to a standard sufficient for their touristic exploitation. Operating strictly on the premise that historical sites and natural beauty presented the only potential points of touristic interest in all of the aforementioned countries, the consultants travelled to assess the respective sites in question, and the country in general, according to their destination value. In most cases, the experts were affiliated not with the field of tourism or economic planning, but rather with the fields of architecture, art history or natural science. Nonetheless, they were tasked with analysing the tourism potential, and counted hotel beds and smooth surface road-kilometres, evaluated the quality of service and attractions offered, and delivered investment and profitability recommendations. Finally, they developed concrete plans and proposals, ranging from legislative and administrative changes to social and urban planning, as well as specific restoration works.

In Ethiopia, Lalibela was the first site of extensive international cooperation and official engagement with the Ethiopian government to restore the monuments and provide for their conservation. Initially, Ethiopia requested to launch

90 N.N., "Cultural Tourism: The Unexploited Treasure of Economic Development", UNESCO Courier 19, no. 12 (1966): 11-13; Unesdoc, “UNESCO. Executive Board; 72nd Session; 1966,” n.d. 91 Decisions taken during the Sixth Review of Operational Projects financed from UNDP, UNFPA and under funds-in-trust, May 1982, in: UNESCO 069:72 (63) UNDP pt. ixb; surely a comparative study of all the countries would bring fruitful insights regarding the influence and role of these missions. 
an international safeguarding campaign modelled after the Nubian Monuments Campaign. Even though UNESCO did not want to commit to a full-sized safeguarding campaign immediately, "they wanted to prove that His Imperial Highness' appeal to them was met with favour, they approved the idea of sending immediately to Ethiopia, at their own expenses, an expert to make financial estimations and technical suggestions about the restoration, provided that the Ethiopian party took charge of the local expenses (hotel and transport) of the said expert." 92

This resulted at the beginning of 1965 in a joint suggestion by UNESCO and the American Society of Archaeology to the International Fund for Monuments, a newly founded American organisation (whose Chairman was Colonel James A. Gray), which "immediately agreed to make the Lalibela Project the first one to be launched by the new organization."93 These efforts were later considered by UNESCO and UNDP staff as a kind of preparation for further successful international projects in Ethiopia. ${ }^{94}$

Soon after the works in Lalibela began, UNESCO's first mission concerned with the institutional advancement of Ethiopian heritage-making dispatched Richard Howland, Professor for Archaeology and Art History, Secretary-Treasurer of the U.S. National Committee of ICOMOS and chairman of the Department of Civil History at the Smithsonian Institution in Washington, D.C., in 1967 to bring forth "practical recommendations and suggestions [...] for those who have the heavy responsibility for developing an Antiquities Administration for Ethiopia."95 This endeavour resulted in a report entailing Recommendations for the Organization of the Ethiopian Antiquities Administration. The technical director of the Lalibela project, architect Sandro Angelini of ICCROM, oversaw and planned the restoration work, but returned for follow-up missions with a more general scope.

Ian Grimwood and Leslie Brown had already stated in their report that only tourism would provide the justification to install conservation institutions that could successfully carry out "the primary task of conservation, believing that

92 S. Pierre Pétrides, Memorandum on the Project for Restoration and Conservation of the Monuments of Lalibela, in NALE, 1.2.26.5, Lalibela Committee.

93 Ibid.

94 Such as the ETH 74/14 project: "Lalibela was also the place where the project could record massive progress of work - succeeded in close cooperation with the local administration and the church itself.” Draft report of the Tripartite Meeting from 27.1.1978, in: UNESCO 069:72 (63) UNDP, pt. vi.

95 "Recommendations for the Organization of the Ethiopian Antiquities Administration: Ethiopia - (Mission) February-March 1967 [Serial No. 89/BMS.RD/SHC]" (Paris: UNESCO, 1967), 1; Richard H. Howland, “Journey to Ethiopia’s Past”, UNESCO Courier 20, no. 11 (1967): 39-42. 
conservation alone would not provide enough priority and incentive in the eyes of the Ethiopian government." 96 Indeed, the issue of cultural and natural heritage attracted attention as an item of development planning due to its potential for creating tourist destinations and establishing tourism as an economic sector in Ethiopia. In 1968 the Ministry for Planning and Development submitted a request to UNESCO to send an expert for legal and organisational aspects of cultural heritage, so as to build a systematic foundation for the development of sites of cultural heritage as tourist destinations. ${ }^{97}$

The Cultural Heritage division of UNESCO had its eye on Ethiopia, as did the UNDP regional representative in Addis Ababa, with the objective in mind to execute a larger-scale project, combining development planning, tourism and conservation of monuments, and presented this possibility to the Ministry of Planning in $1968 .^{98}$ In pointing to the possibility for a larger amount of funding to be made available as a follow-up to the initial project, UNESCO managed to secure the interest of the Ministry of Planning, which added considerable weight to the cause of conservation. Together with the economist Louis Mougin, in 1968 Sandro Angelini offered a report titled Proposals for the development of sites and monuments in Ethiopia as a contribution to the growth of cultural tourism. ${ }^{99}$ Two years later in 1970, the consultant B.G. Gaidoni conducted a study on Cultural Tourism: Prospects for its Development. ${ }^{100}$ All of these missions contained, in parts, recommendations to the institutional organisation of the heritage-making institutions as well as the legislation regarding heritage.

Tourism presented a recurring component of all conservation activities in Ethiopia. For many it carried a promise of salvation for developing countries, and several targeted activities guided by that belief were initiated within UNESCO and other institutions like UNECA and FAO during that time. These included surveying the touristic potential of countries based on economic prospects or infrastructural investment schemes that aimed to improve the standard of tourist destinations and make them more accessible. In this zeitgeist, another

96 Grimwood, "Conservation of Natural Resources", 2.

97 Letter from Belai Abbai to Malcolm Adiseshiah, 4.1.1968, in: UNESCO X 07.21 (63) AMS, pt. ii. 98 Response to letter from Malcolm Adisehsia to Belai Abbai, 14.2.1968, in: UNESCO X 07.21 (63) AMS, pt. ii.

99 Sandro Angelini and Louis Mougin, "Proposals for the Development of Sites and Monuments in Ethiopia as a Contribution to the Growth of Cultural Tourism: Ethiopia - (Mission) May-June 1968 [Serial No. 893/BMS.RD/CLT]” (Paris: UNESCO, 1968).

100 B.G. Gaidoni, "Cultural Tourism; Prospects for Its Development: Ethiopia - (Mission) September-October 1969 [Serial No. 2031/BMS.RD/CLT]” (Paris: UNESCO, 1970). 
of Sandro Angelini's missions in 1971 finally brought a concrete working plan for the development of individual sites alongside the "Historic Route" to the table. ${ }^{101}$

\section{Doing cultural tourism in Ethiopia}

In the eyes of the heritage experts, the existing heritage sites were merely a few diamonds in the rough, loosely strewn across the country. The international experts perceived a dire need for structural improvement, conservation and image promotion. Gaidoni, the only UNESCO expert dealing with Ethiopian tourism development with a specific background in tourism expertise, travelled along the "Historic Route" and, although he admitted that the monuments needed restoration and protection from vandalism and weathering, his main concern was the lack of destination value from the presumed tourist's point of view. In addition to the improvement of hotel facilities, the service and number of available beds in general, his assessment was characterised by the idea that the monuments alone would not create enough value to make travel there worth the tourist's while and money. For Lake Tana, he proposed, after an initial restoration of the churches on the Lake's islands, the addition of sailing clubs, fishing lodges, bathing establishments and more, to "insure [sic] that visitors will come". For Gondar, he suggested a golf course, tennis courts and bowling grounds-clearly having the European/British upper-class tourist in mind. ${ }^{102}$ And, for Lalibela: "Entertainment is totally lacking. At least a small cafe or bar should be built [...]. A miniature golf and a swimming pool would add diversion for the tourist, because visiting the churches in the villages [...] would take more than one day."103

With all the modernisation and addition of leisurely facilities for the tourists' sake, however, he cautioned that "the alteration to the character of the locale and to the landscape that these suggested changes would inevitably introduce, must be confined to the already urbanized areas" so as "not to alter in the least the appearance and authenticity of these other localities". He wrote further that, "It would be a pity to destroy the possibility of the elation of discovery."104 Most noteworthy are Gaidoni's suggestions to not only improve the monuments as sights, but also to establish a showcase of local arts and crafts, as well as per-

101 Sandro Angelini, "The Historic Route: A Work-Plan for the Development of the Sites and Monuments: Ethiopia - (Mission) June 1971 [2468/RMO.RD/CLT]” (Paris: UNESCO, 1971).

102 Gaidoni, "Cultural Tourism”, 24.

103 Ibid., 38.

104 Ibid., 17-18. 


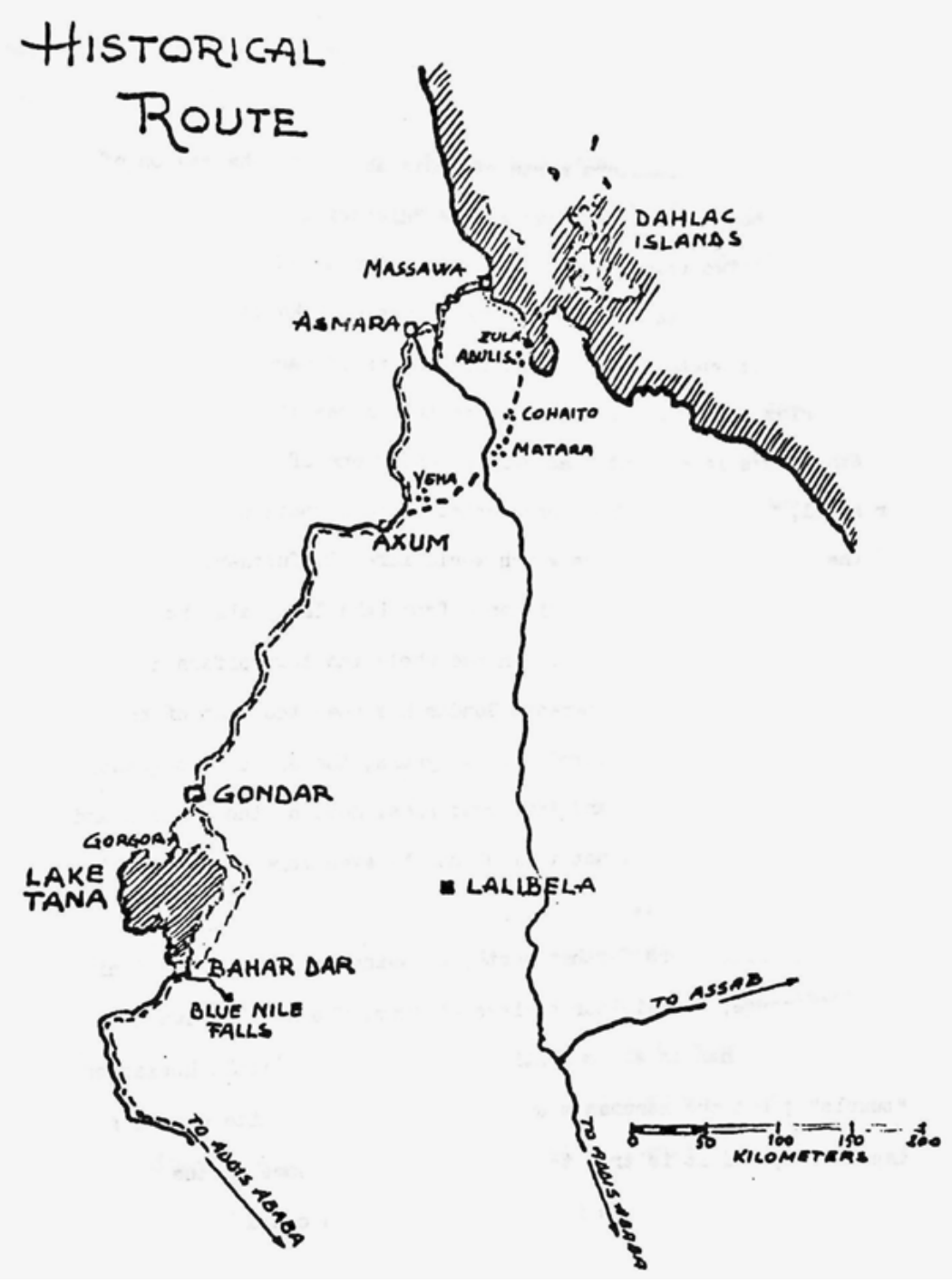

Figure 2: Historical Route, Gaidoni, 11.

formances for the purpose of tourist entertainment. He suggested to enable the government to take ultimate control over the manner of representation of the varied local ethnic identities of Ethiopia. 
In accordance with the idea that tourism to the country's heritage sites would improve economic development, the first natural and cultural conservation consultancies and projects were concerned as much with tourism as with the heritage sites themselves. ${ }^{105}$ In the project reports, the internationally acclaimed architects, art historians and wildlife experts who were sent on these consultancy missions by UNESCO relentlessly emphasised the contribution that the development of historical monuments and sites would provide towards the growth of tourism.

The experts' assessment of the tourism potential of individual heritage sites and their surrounding regions had a direct influence on which sites were given priority in the direction of international funds and national institutional capacities for conservation. Furthermore, it influenced the general programmatic direction of heritage-making in Ethiopia. Grimwood and Brown emphasised in their reports that a large enough touristic potential would only be created with a combined promotion of natural and cultural heritage, acknowledging at the same time the greater relevance and potential of cultural heritage as opposed to natural heritage. Consequently, the efforts taken in the following years were mainly in the areas of cultural heritage conservation and presentation.

As regards wildlife conservation, tourism underwent a transformation during this period from game safaris towards an emphasis on natural observation and photo safaris, and this process caused the proper development of a consistent strategic approach to suffer. The planning of the "Historic Route" influenced the establishment of natural heritage insofar as the distribution of resources goes. The Simien National Park was chosen as a focal point for these efforts as it was adjacent to the planned "Historic Route", and promised to provide touristic potential because of the unique mountain-riff-scenery as well as the rare species present. ${ }^{106}$

After more than ten years of consultation and conservation efforts through UNESCO's experts, the conditions for heritage-making had matured enough by 1974 to take the next step towards shaping the Ethiopian national heritage in accordance with the universal standards of heritage. Yet despite several preparatory missions, Ethiopian heritage was still not in a position to launch the safeguarding campaign that had been requested and envisaged for it. As another preparatory step, a seven-year project entitled Presentation and preservation of selected sites was launched in 1975, funded and organised by UNDP and admin-

105 Huxley et al., "The Conservation of Nature”; Brown, "Conservation of Nature”; Grimwood, "Conservation of Natural Resources"; Angelini and Mougin, "Proposals for the Development"; Gaidoni, "Cultural Tourism”; Angelini, "The Historic Route”.

106 Gaidoni, “Cultural Tourism”, 49. 
istered by UNESCO. ${ }^{107}$ This project was deemed necessary to build up in the first instance the national capacities for receiving and putting to use international donations for safeguarding that would be made available with the campaign launch. ${ }^{108}$

Originally the project ETH 74/14 was titled The Development of Cultural tourism: preservation and presentation of sites and monuments ${ }^{109}$ and with the new raison d'être of heritage sites as tourist destinations, the project qualified as one of the "sharper focus and greater impact potential [...] projects which are economic but which have maximum multiplier effects"110 that UNDP tried to establish as a priority in Ethiopia. Although after a personal visit the UNDP resident representative Alan Elliott was doubtful in internal correspondence about the realistic possibilities, in the official language of reports and requests and also correspondence with the Ethiopian authorities, the promotion of tourism was enthusiastically defended and fostered by UNDP and UNESCO representatives. ${ }^{111}$ After the first several missions, UNESCO acknowledged that the government would need more assistance to "promote tourism and increase the value of cultural heritage and natural sites."112

After the 1974 revolution, the government still desired the development of tourism, but its valuation shifted. ${ }^{113}$ The declaration on "Economic Policy of Socialist Ethiopia by the Provisional Military Government of Ethiopia”, issued on February 7, 1975, stated that, "It should, however, be emphasised that the conservation of wildlife, birdlife, etc. particularly of the rare species, and the preservation of the antiquities will be viewed primarily as national objectives in their own right and not only as a means of attracting foreign visitors." ${ }^{114}$ Although in the UNDP country programme for Ethiopia for the period 1983-86 the UNDP still stated "the high importance which the Ethiopian government accords to the dimension of culture in the development process", ${ }^{115}$ the development of heritages

107 UNDP/ETH/74/014, Terminal Report, 1.

108 The campaign was acknowledged by UNESCO's General Conference in 1976 (resolution 19 C/4.126), but not implemented until 1988; International campaign to safeguard the principal monuments and sites of Ethiopia-campaign strategy and action plan 1988-1997, May 1988, in: ARCCH, 14-1, UNESCO, Folder 1.

109 Project proposal, no date, in: UNESCO 069:72 (63) UNDP, pt. i.

110 Memo from E. Amerding, in: UNESCO 069:72 (63) UNDP pt. i.

111 Memo from A. Elliott to Director BMS, 21.1.69, UNESCO X 07.21 (63) pt. v.

112 Memo from Director BMS to DG, October 1970, in: UNESCO X 07.21 (63) pt. vi.

113 Aleme Eshete, The Cultural Situation in Socialist Ethiopia (Paris: UNESCO, 1982), 19.

114 Quoted in: Ayalew Sisay, Historical Development of Travel and Tourism in Ethiopia (Addis Ababa: the author, 2009), 162, 163.

115 Letter from J.B. Kabore, to Mr. K.F.S. King, UNESCO 069:72 (63) UNDP pt. ixb. 
sites as destinations was no longer considered as important. In reality not only the re-orientation of the political paradigm but mainly the ongoing political and military conflicts presented a strong inhibiting factor for all tourism activities. Travel bans and states of emergency made large parts of the "Historic North" inaccessible to foreigners for almost a decade. In the years between 1983 and 1988, the tourism sector had a very low priority, as over a third of the national budget was allocated to defence and internal security. The nationalisation of all private hotels, tour operators and agencies prevented any possibility of foreign private investment. Furthermore, tourism suffered from the continuous lack of infrastructure and from insufficient marketing. ${ }^{116}$

UNESCO and UNDP representatives attempted to adapt the project guidelines to the new political directions and paradigms of a new administration which refused to see culture as complimentary or to be simply employed in the service of tourism and economic development, and emphasised how "for the preservation of cultural heritage, in this context a development of cultural identity would provide important guidelines for economic development, in which tourism components were not vital, but would be a result."117

\section{Turning the heritage sites into destinations}

While the development of tourism never did accomplish what had been predicted in the 1960s, the promotion of tourism and the scientific expert evaluation of heritage sites were however of major importance in helping create a tourist image of Ethiopia. Experts agreed early on that any planning had to revolve around creating a strong image of Ethiopia that would have a specific appeal to tourists. According to the UN tourism expert Vojislav Popovic, Ethiopia's main asset in terms of tourism was, in fact, not the mass-tourism market flowing into coastal resorts or which looked for easy, pre-arranged "wildlife-coast" pack-

116 The independence of Eritrea resulted in the loss of some of the most promising tourist destinations along the Red Sea coast, according to: Frederick A. Frost and Tekle Shanka, "Perception of Ethiopia as a Tourist Destination”, Ethiopia in Broader Perspective: Papers of the XIIIth International Conference of Ethiopian Studies 348-50 (1997). Until the 90s, the tourism brochures from the $60 \mathrm{~s}$ and $70 \mathrm{~s}$ presented the only tourism promotion material available and they are today still sold at souvenir stalls at the tourist destinations, supposedly because no new ones exist in sufficient quantity.

117 Draft report of the tripartite meeting from 27.1.1978, Project ETH/74/014, in: UNESCO 069:72(63) UNDP pt. vi. 
ages, but its "appeal [...] to the well-to-do, sophisticated sightseeing tourists". ${ }^{118}$ These were the experienced international travellers seeking out the unique and largely different attractions of Ethiopia: unspoiled nature, fascinating landscapes, numerous ethnic groups and "the long history of independent rule, the traditional dynasty whose origin is interwoven with legend of the pre-Christian era [...which] make Ethiopia a country whose original features can very well be used to create a touristically very attractive image in the minds of the public and tour organizers.”119

Like Popovic, Gaidoni stated that "the first and most urgent task in the process of building a tourist industry in Ethiopia must be the creation and diffusion of the tourist image of the country." He sketched out:

First, like Egypt, Ethiopia has its own unique architectural and historical reality, with sites like Gondar, Axum, and Lalibela as outstanding tourist offerings. Secondly, like Kenya, Ethiopia boasts the wildlife resources of its national parks, Awash, Simien, and Bale. Lastly, Ethiopia betters either Egypt or Kenya with its sunshine and sea beauty, Massawa, the Dahlak Islands, and in general the Red Sea coast. This Ethiopia can offer a triple image, but because Ethiopia is also an African country, this image must be thoroughly African. What I mean is this: Even if Ethiopia is building modern cities and new industrial enterprises, it has to offer the tourist points of interest he does not find at home, be that in Europe or North America. It is this other world image which must be established to attract the attention of the prospective tourist. The proper tourist image, then, is the first thing an ETO team of experts should establish. ${ }^{120}$

The establishment of tourism as a state economic sector had a strong impact on both image production and the circulation of knowledge of Ethiopian heritage. In order to attract foreign investment and to promote Ethiopia as tourist destination on the international market, two government institutions were put in charge of tourism marketing concepts and campaigns: EAL and the ETO. Both institutions received foreign technical assistance and foreign advisors contributed significantly to the production and planning of tourism images and slogans. Tourism promotion experts from Germany, the UK and France, funded via bilateral programmes of technical cooperation, worked for the ETO, developing tourism promotional materials that would advertise the benefits of Ethiopia in the language of Western commercial advertising. ${ }^{121}$ EAL's early tourism promotion al-

118 Popovic, Tourism in Eastern Africa, 92.

119 Ibid., 90.

120 Gaidoni, "Cultural Tourism”, 7.

121 At least six full-time advisors, two of which were responsible for the development of publicity, over a duration of several years, are listed in the following reports: UNDP, "Report on Development Assistance to Ethiopia in 1972 - Prepared by the Resident Representative of the UNDP 
ready operated with catchy slogans, such as "The Wonderland Route" or "The Land of Queen of Sheba”, alluding to the Western fascination with Ethiopian heritage and history. ${ }^{122}$

The director of the ETO was Habte Selassie Tafesse, formerly head of the press and information department of the Ethiopian Imperial Ministry of Foreign Affairs, and head of Tourism in the Prime Minister's Office. He received his primary education and socialisation growing up in Athens as the foster child of a Russian Orthodox Christian family, and his secondary education in Alexandria, Egypt, where his Ethiopian birth father served as ambassador for Ethiopia. He received his higher education in the USA. ${ }^{123}$ He brought a decidedly Western, state of the art expertise, and sense for marketing and image promotion to all areas of government publications directed towards a foreign audience. ${ }^{124}$

After the establishment of the ETO in 1966, a full-scale marketing strategy was developed under his direction, including the slogans "The hidden empire" and "13 months of sunshine", which referred to the Ethiopian use of the Julian calendar as opposed to the Gregorian one, resulting in an additional month ${ }^{125}$ and implying, in the marketing copy, not only the benefits of a consistently mild and sunny climate throughout the year but also that for the tourist more was to be found than expected in Ethiopia. ${ }^{126}$ Habte Selassie also created Ethiopian Pavilions for the World Expositions in Montreal, Canada in 1967 (which can be seen on the cover image of this book) and in Japan in 1972, as well as regularly showcasing Ethiopia at the Internationale Tourismus-Börse (ITB) in Berlin. Part of this strategy was image production that established and curated the sites of cultural and natural heritage as touristic destinations. These images were orientated towards the Western interest in Ethiopia, focusing on exoticised images of "ethnic" faces and singling out monuments. ${ }^{127}$

in Ethiopia," 41, 42; UNDP, "Report on Development Assistance to Ethiopia in 1973" (Addis Ababa: Office of the Regional Representative of UNDP, April 25, 1974), 46, 47.

122 Pamphlets, in NALE 1.2.18.01, Ethiopian Airlines.

123 He spoke Greek, English, French and Russian but was not a native Amharic speaker.

124 Interview between Arefayne Fantahun and Habte Selassie Tafesse, May 2016 in Addis Ababa, notes kindly provided to me by Arefaynie Fantahun; Tafesse Habte Selassie, "Tourism". 125 To balance out the leap year.

126 Ethiopian Tourist Organisation, 13 Monate Sonnenschein in Äthiopien, 1971.

127 The images of the posters to the thirteen month campaign were and are widely popular and can still be found serving as decoration in Ethiopian restaurants today. Personally, I have seen them in every Ethiopian restaurant I have visited so far, in Berlin, London and Oakland, CA. Furthermore, in Facebook-groups dedicated to sharing historical photos of Ethiopia, these images are frequently shown and continue to circulate. 
For the planning of tourism in Ethiopia, the establishment of a portfolio of historic sites along the "Historic Route" was firmly connected to the belief that only these sites held enough potential to attract larger number of tourists, deemed a necessity to onset the general touristic development of Ethiopia. ${ }^{128}$ After the overall tourist development plan from 1969, another plan was commissioned with a US-consulting firm, selecting that tourism investment and development should be concentrated on the "Historic Route" for the decade 1970 1980, and be connected to the establishment of a chain of eight first-class hotels along the "Historic Route". ${ }^{129}$ The "Historic Route" formed the core of the marketing strategies of both EAL and the ETO, which published numerous pamphlets, books, posters and brochures. More than thirty different pamphlets, dedicated to individual places or activities of touristic interest, demonstrate the broad scope that tourism development enjoyed for a brief period: guides for day trips from Addis, fishing, camping, diving, white-water rafting, as well as pottery, jewellery and wild flowers. ${ }^{130}$ For the period of two years, a monthly newspaper, Tourist News, was published by the ETO in English and French (as nouvelles touristiques), containing a rotating stock of articles about the main sights as well as changes in current information. ${ }^{131}$ At the core of the promotional material remained the "Historic Route" or the "Historic North" and most of the guidebooks published are decorated on the cover with isolated, iconic images of the classic heritage sites in Lalibela, Axum, Gondar and Simien, or contain a map of Ethiopia assembled of nothing but the images of the main heritage sites.

Archaeologists of the French "Institut éthiopien d'études et de recherches" as well as heritage experts working for the government authorities for cultural heritage (CRCCH) and wildlife (EWCO) contributed texts and images towards the production of the brochures and travel guides published by the ETO, such as the brochure Big Game, which was produced in collaboration with John Blower-who served as the director of EWCO-or Ancient Sites of Northern Ethiopia,

128 Angelini and Mougin, "Proposals for the Development", 5; Grimwood, "Conservation of Natural Resources”, 6;

129 Ayalew Sisay, Historical Development of Travel and Tourism in Ethiopia (Addis Ababa: the author, 2009), 110 -12; Ethiopian Tourist Organisation and PPR International, London, Ethiopia - Opportunity for Investment in a New Chain of Tourist Hotels, n.d.

Ayalew Sisay, Historical Development, 110 -12; Ethiopian Tourist Organisation and PPR International, London, Ethiopia - Opportunity for Investment in a New Chain of Tourist Hotels, n.d. 130 A complete list of all examples found during my research is attached in Appendix I.

131 Ethiopia Tourist News, Monthly Publication of the Ethiopian Ministry of Commerce, Industry, and Tourism and ethiopie nouvelles touristiques, Publication Mensuelle du Ministere Ethiopien du Commerce, Industrie et Tourisme. 
which included texts by Francis Anfray, archaeologist at the French Institute. ${ }^{132}$ Within just a few years, an array of symbolic images of Ethiopia was created that helped to manifest the key tropes of ancient empire and isolated natural beauty as icons representing Ethiopian history and heritage.

This gave experts a double function, turning them, in addition to their expert role, into mediators of knowledge to an interested, educated Western public. A particularly vivid example is the round trips organised by the British Swan Tours in 1972-73. Four "special interest tours" altogether were taking place in Ethiopia, with renowned scholars of Ethiopian Studies accompanying the tours as guides-Richard and Rita Pankhurst, historians and political activists for the Ethiopian cause, two key figures for the scientific and political development of Ethiopia in the twentieth century. Other tours were guided by Sir Patrick Kirwan, a British archaeologist who had undertaken research in Axum among other sites in the Horn of Africa, and the historian Edward Ullendorf. ${ }^{133}$ In a similar manner, in 1971, the US American Wilderness Expeditions Inc. offered a guided "Ethiopian Highlands Tour", advertising that for ten of the fourteen days of the tour, the group would be accompanied by British-Kenyan zoologist Leslie Brown, a seasoned wildlife advisor to international organisations, as well as to the Ethiopian government, who also lectured at the university in Addis Ababa. In the advertisement for the tour, beneficial effects of tourism to the Ethiopian highlands were emphasised: "The influence of international travelers can be determinative on this issue [environmental degradation through agriculture], as Ethiopia is most anxious to develop tourist trade. And few tourists will be anxious to visit a burnt-out and plowed under wasteland devoid of wildlife."134

\section{Consulting and the tourist gaze: UNESCO's cultural tourism development projects}

How did the promising and paternalistic tourism plans translate into reality? During the 1960s many African countries indeed started to see the arrival of tou-

132 John Blower, Big Game in Ethiopia: Hunting and Photographic Safaris in Africa's Newest Game Country (Addis Ababa: Ethiopian Tourist Organization, 1984); Ethiopian Tourist Organisation and Francis Anfray, eds., Ancient Sites of Northern Ethiopia, 1967.

133 Swan (Hellenic) LTD, 1972-73 special interest tours of Ethiopia, 15.6.72, in: SOAS Kirwan papers, Box 4, 3-70.

134 Wilderness Expeditions Inc. - Ethiopian Highlands 1971, in: IES, Tourism Miscellanea 5. 
rists, but the situation and the results varied tremendously between countries. ${ }^{135}$ In some countries, for example Morocco and Tunisia, the tourism sectors were economically beneficial, but the necessary sectorial investments still left the tourism sector as a net consumer of surplus, meaning that the overall profit from tourism was still lower than the investments. This created a positive balance for economic development but a negative one for the gross national product. For some countries on the other hand, such as Kenya and Tanzania, earnings through tourism were relatively weak but still a major contributor to GNP and presented, for some years at least, the largest source of foreign currency in otherwise weak economies. According to Kenyan geographer Joseph B. Ouma, who undertook tourism research during geographical fieldwork inEast Africa, in 1968, tourism presented the largest source of foreign currency for some East African countries like Kenya, Uganda and Tanzania, and it was a vital factor of economic development, even ahead of coffee or tea. ${ }^{136}$ In the end, differences between individual developing countries were large and not easy to explain, let alone to compare or transfer, in effect rendering the prognosis behind the tourism development policies of ECOSOC, UNCTAD and the respective expert studies as pure speculation. ${ }^{137}$

In reality, in many countries the growth of a national tourism sector was inhibited by the lack of effective state policies. Furthermore, the allocation of resources, consistent sectorial planning and a feasible integration of tourism in national development plans was beyond the capacity of many governments. In fact, it was often the case that an increase in tourist arrivals didn't necessarily result in corresponding growth in the tourist sector. Package tours, organised by European or North American tour operators, were often completely devoid of any substantial effect on the national economy of the destination country, as the profit was earned in the tourists' country of origin. This resulted in a very low rate of gross foreign exchange inflow, with the operators having no viable interest in buying and hiring locally, justifying their decision by referring to the insufficient standard available. The introduction of protectionist European airport and char-

135 United Nations Conference on Trade and Development, Elements of Tourism Policy in Developing Countries - Report by the Secreteriat of UNCTAD, United Nations Publication, E.73. II. D.3TD/B/C.3/89/Rev.1 (New York: United Nations, 1973), 6-7.

136 Joseph P.B.M. Ouma, Evolution of Tourism in East Africa (1900-2000) (Nairobi: East African Literature Bureau, 1970), preface.

137 Herbold Reginald Green, "Towards Planning Tourism in African Countries", in Tourism: Passport to Development? Perspectives on the Social and Cultural Effects of Tourism in Developing Countries, ed. Emanuel de Kadt, World Bank, and UNESCO (Oxford; New York: Oxford University Press, 1979), 80. 
ter-flight regulations made it impossible for African and Asian airlines themselves to operate flights for tourists from Europe to their countries, adding to that negative effect. ${ }^{138}$ It was a catch-22 situation: countries that lacked funds to provide the necessary infrastructure also lacked the tourists required to generate the critical amount of income necessary for these funds.

Nevertheless, while these countries served as examples of the positive impact of tourism on economic development, presenting exaggerated prognoses for the economic benefit was a common strategy in consultant reports to stimulate a maximum amount of investment and follow-up funding. International experts' assessment usually led to the inclusion of their recommendations in the national five-year development plans, prompting the launch of further technical assistance for infrastructure and vocational training, for preservation and for the presentation of sites. Technical assistance linked to conservation and tourism carried with it secondary benefits in terms of infrastructural investments and tourism development opened up yet another line of argumentation for large projects from the World Bank or similar donor organisations. ${ }^{139}$

The positive expectations of the potential benefits and outcomes of tourism were tempered by strong criticism which questioned not only these promises and potential benefits, but also drew attention to the negative impact and inherent risks for the destination countries in the developing world. The promises of tourism remained a dream removed from reality for many countries and a strong critical tourism discourse emerged in parallel from the 1960s. Because of the general skills shortage in many developing countries, tourism development would not only cause a brain drain from more important sectors, but would also necessitate a high cost in expatriate skills. Due to its complexity and context-sensitivity, tourism was declared to be a highly unsustainable economic product. Anchored in a scientific analysis of sociocultural costs and benefits, studies aimed to show the exploitative tendencies of speculative land booms, the high investment nec-

138 Ibid., 83, 89; N.B. Salazar, “A Troubled Past, a Challenging Present, and a Promising Future: Tanzania’s Tourism Development in Perspective”, Tourism Review International 12, no. 3/ 4 (2008): 4-6; John Sorana Akama, "Neocolonialism, Dependency and External Control of Africa's Tourism Industry: A Case-Study of Wildlife Safari Tourism in Kenya”, in Tourism and Postcolonialism: Contested Discourses, Identities, and Representations, ed. C. Michael Hall and Hazel Tucker (Abingdon, Oxon; New York: Routledge, 2004), 147-50.

139 Emanuel de Kadt, "Introduction", in Tourism: Passport to Development? Perspectives on the Social and Cultural Effects of Tourism in Developing Countries, ed. Emanuel de Kadt, World Bank, and UNESCO (Oxford; New York: Oxford University Press, 1979), 11; Frank Mitchell, "The Value of Tourism in East Africa” (Discussion Paper No. 82, University College, Nairobi, Institute for Development Studies, Social Science Division, n.d.), 7; Ouma, Evolution of Tourism in East Africa, 77. 
essary to create jobs in the tourism industry and the reinforcement of divisions along social strata through large scale developments. ${ }^{140}$

One of the responses that developed from the criticism of (mass) tourism was the concept of cultural tourism. One paradigm of tourism that guided commercial expansion and touristic enterprises was "bringing the known to the unknown", but the detrimental effect of commodifying culture and heritage on local communities and traditional values and cultural practises was quickly raised as an issue. After several studies on the social impact of tourism, the conclusion that tourism presented not only a chance for education and income but indeed a veritable danger to traditional culture in hosting countries became more widespread. In a report from 1974, Peter Lengyel, editor of UNESCO’s International Journal of Social Sciences, shared his observation on cultural tourism in Bali, which was a major focal point where tourism and its effects were perceived as a problem by the political authorities of the country itself: "It would seem to me to be impossible in these days of mass travel for a small but well-known place [...] to maintain its culture in a frozen state since obviously the changing life and the consciousness [of the local population] will cut them off increasingly from their own roots."141

He argued for an international responsibility to empower local culture, and educate and train the local population better so they would have something to shield them from the "tastes of undiscriminating Philistines", ${ }^{142}$ who were just trophy-hunting for objects that resembled their imagination of the destination. Cultural tourism provided an alternative to tourism as a means to increase economic development or for profit, and was supposed to curb the destructive impact of economic principles on cultural identities and communities. Through efforts such as sensitive marketing arrangements, the government-guided production of arts and crafts souvenirs, or planning codes aiming to create an "integrated environment", one that is beneficial for locals and tourists alike in

140 This critical discourse marked the beginning of an orientation in anthropological tourism research towards the impact of tourism, establishing concepts such as John Urry's theory of the "tourist gaze" and its transformative power on host societies: de Kadt, World Bank, and UNESCO, Tourism: Passport to Development?, 34-49; Lanfant, "Tourism”, 17-22; Walter van Beek and Annette Schmidt, "African Dynamics of Cultural Tourism”, in African Hosts \& Their Guests: Cultural Dynamics of Tourism, ed. Walter van Beek and Annette Schmidt (Woodbridge, Suffolk; Rochester, NY: James Currey, 2012), 1-33.

141 Report on cultural tourism in Bali from Mr. Peter Lengyel, January 1974, in: 069:72:380.8 A 193.

142 Ibid. 
historic urban centres, cultural tourism was believed to help the preservation of cultural and craft traditions. ${ }^{143}$

In reality, UNESCO's cultural tourism assistance projects were not exactly a counter-concept, but merely an attempt to connect some of UNESCO's cultural concerns to a more widely recognised line of argumentation for development assistance. When promoting the issue of cultural tourism and conservation to governments of developing countries, in many cases UNESCO argued for and justified the initiative of projects with the supposed economic stipulation resulting from the projects. In Burma, a request for assistance for conservation was declined, with UNESCO stating it could only give funds if the conservation was for tourism development purposes. ${ }^{144}$ It was declared a prerequisite that firstly tourism had been evaluated as a major source of potential income to the country and then, secondly, the monuments could be proven to contribute significantly to that potential. Through UNESCO a counter-position to the economic focus within the tourism discourse in particular, and the development discourse in general, was voiced, but it remains questionable whether these efforts ever amounted to any significant impact. Just as the economic analysis lacked an understanding of the socio-cultural aspects of tourism development, the reports drawn up by those who were conservators and architects by training lacked economic expertise, yet they included estimates for the capital public and private investments necessary for the planning and development of airport infrastructure and road networks. ${ }^{145}$

Next to an understanding of the technological and economic implications of tourism, it is part of a distinctly modernist discourse, representative of changing worldviews and global-local relationships within the reality of the modern, postindustrial societies of the Global North. As explained earlier, other forms of society in earlier periods had variations of mass travel, the most prominent being pilgrimage, but only in the distinct setting of employed, industrial and post-industrial labour could travel be fully conceptualised as tourism. Per its definition, the technical assistance for the development of tourism was confined to develop-

143 Emanuel de Kadt, “Arts, Crafts, and Cultural Manifestations”, in Tourism: Passport to Development? Perspectives on the Social and Cultural Effects of Tourism in Developing Countries, ed. Emanuel de Kadt, World Bank, and UNESCO (Oxford; New York: Oxford University Press, 1979), $68-76$.

144 Letter from Hiroshi Daifuku to T.R. Gairola, 21.5.1970, in: 069:72 (591) AMS. Document courtesy of Clara Rellensmann.

145 Angelini and Mougin, "Proposals for the Development”, Annexes 3 ,4, 5, 6, and 9; J.C. Pollacco, "Nepal - Development of Cultural Tourism” (Paris, September, 1968: UNESCO, n.d.), $12-18$. 
ing countries. The experts, however, were of Western provenance. ${ }^{146}$ When these experts spoke of tourism in their reports, they operated strictly on the basis of the imagined potential of tourism coming from Western countries to the socalled developing ones.

In a study commissioned in 1968 by the UNECA, the UN tourism expert Vojislav Popovic argued for the tourism potential of Eastern African countries in particular based on the steady rise of the average disposable income in Western countries. Given the equidistant location of Eastern Africa to Western tourists' countries of origin in comparison with more established destinations, ${ }^{147}$ he argued further that it would only be a matter of developing competitive destination values and promoting them effectively. He identified the North American and the Japanese markets as the most relevant target groups for marketing and pricing strategies, necessitating a focus on reducing the cost of transportation as a first step, and in shaping the tourist attractions to the liking of American tourists as a second $\operatorname{step}^{148}$. According to Popovic, leisure and nature would be not be interesting enough for American tourists to travel overseas, but cultural performances, artefacts and places would do the trick: “American tourists are genuinely interested in people, their way of life, both modern and traditional, old customs, folk dances and songs, old architecture, large cities, shopping, handicraft, and with good promotion a considerably larger number of American tourists may become equally interested in wildlife."149

Spending power existed mainly in Western countries and among African elites, and developing countries were marketed as destinations using images that would reflect the ideas of Western customers or alluded to upper class ideas of leisure. Cultural heritage and practices were transformed into "intangible products" and "aesthetic services", ready to be consumed by tourists. ${ }^{150}$ Perceptions of these countries were shaped according to orientalist, exoticist ideas and UNESCO engaged and accelerated the production of these images with its

146 As an exception could be considered the chairman of the Maltese Tourism Commission, who served as an expert advisor for the report on Nepal, while at the same time the Maltese government received a similar mission: J. Mougin, "Malta - Conservation of Sites and Monuments in the Development of Tourism” (UNESCO, 1967); E.A. Connally, "Nepal” (UNESCO, 1968).

147 Such as the Middle East (including Turkey and Greece), the USA, Canada, Mexico, the Bahamas, Jamaica, Bermuda and Trinidad and Tobago: Popovic, Tourism in Eastern Africa, 16-17. 148 Ibid., 17-24.

149 Ibid., 25.

150 What Jonas Larsen and John Urry describe as "intangible products" and "aesthetic services”: Jonas Larsen and John Urry, The Tourist Gaze 3.0 (London; Thousand Oaks, CA; New Delhi; Singapore: SAGE, 2011), 77, http://dx.doi.org/10.4135/9781446251904. 
cultural tourism missions and publicity activities. ${ }^{151}$ Often, the development experts' assessment extended beyond the economic sphere, going as far as to praise the supposedly beneficial "social welfare" effects that the mere presence of tourists (which they imagined as rich, white foreigners) would have for the local people. The type of tourism promoted by the UNESCO cultural tourism missions was related more to the historic origins of tourism from British and French upper-class travels, the Grand Tour, than to the mass tourism phenomenon and thus enhancing the discursive quality of heritage activities as a representation of a Western worldview. ${ }^{152}$

A very influential doctrine held by many experts and politicians was that many developing countries, especially in Africa, were virtually bare of raw resources or the potential to modernise and industrialise fast enough to keep pace with a growing global economy. In order to achieve significant earnings of foreign currency, the key object was to find a trade that would make it possible to achieve the maximum amount of commodification without requiring a large investment or any industrial production. ${ }^{153}$ Tourism promised to readily deliver on that expectation and was seen as the most valuable export product for some countries. Experts commonly made gross generalisations, claiming that tourism would soon be "the fastest growing and potentially the largest single East African foreign exchange earner". After his 1960 mission for the conservation of wildlife in East Africa, Julian Huxley summarised and emphasised what many believed to be the solution for East Africa in particular:

The total revenue from tourism in the four territories of East Africa together is today well over [GBP] 10.000.000. I would prophesy that this could certainly be increased fivefold, and quite probably tenfold, within the present decade. So long as Western prosperity continues, with Western populations (and their revenues) increasing and Western industrialization being intensified, it is safe to forecast that more and more people will want to escape farther and farther from it and its concomitants, in the shape of over-large or over-crowded cities, urban sprawl, noise, smog, boring routine, deprivation of contact with nature, and general over-mechanization of existence. Air travel will certainly become cheaper and more popular, and will be able to take more people farther afield on more adventurous journeys. Given that there is no major war in the world and no outbreak of violent disorder

151 Nigel Morgan and Annette Pritchard, Tourism Promotion and Power: Creating Images, Creating Identities (Chichester, NY: Wiley, 1998), 165-67, 211-12; C. Michael Hall and Hazel Tucker, "Introduction", in Tourism and Postcolonialism, ed. C. Michael Hall and Hazel Tucker (London: Routledge, 2014), 9-10.

152 Patrick Young, "A Place Like Any Other?: Publicity, Hotels and the Search for a French Path to Tourism", in Touring Beyond the Nation: A Transnational Approach to European Tourism History, ed. Eric G. E. Zuelow (Farnham, Surrey: Ashgate Publishing, Ltd., 2011), 130 - 32.

153 Watterson, Conservation of Nature, 22. 
in our region, an increasing proportion of this population of travellers could be readily induced to make eastern Africa their goal. ${ }^{154}$

The stereotypical images and imperialist thinking shining through in Julian Huxley's argument here were characteristic for the tourism planning language. Experts considered tourism to East Africa to be fuelled mainly by the "growing preference of the European public for sunny and warm climates", and the desire to enjoy "unspoiled nature, including tropical forests, magnificent waterfalls, lovely lakes, unusually scenic mountains", ${ }^{155}$ features perceived to be on the decline in Europe due to the transformation of landscapes through industrialisation and the spread of high-density urban agglomerations. Natural conservation experts agreed: "The National Parks and reserves of Africa have a wonderful opportunity of filling a world need-modern man's craving for contact with nature."156

As regards UNESCO and the experts working as consultants on the tourism missions, the tourism assistance offers a glimpse into the mechanics and workings of the international system during a crucial period of growth. Possessing an area of operations in the field of tourism development gave UNESCO a means to increase its influence and relevance. Carrying out these studies helped UNESCO and its commissioned experts to strengthen their role as producers and brokers of knowledge within the development discourse and beyond. It sheds light on the fact that international organisations like UNESCO and their international policies provided a hub for a multitude of interests, bestowing a label that could easily be appropriated in different ways by the different actors involved. As already stated, for many governments, one of the biggest immediate economic benefits of tourism development was its potential to open up further possibilities for accessing large scale infrastructural development funding.

Without the economic incentive of cultural tourism, no funding would have been available for developing countries to put into effect the conventions regarding heritage protection. Projects, such as the creation of inventories or scientific evaluation according to the elaborate standards of ICOMOS, would not have been possible through the existing development budgets of the Participation Programme, Funds in Trust or the World Heritage Fund. Larger projects, such as institutional development and legislation in Ethiopia, were necessary in many developing countries to meet even the basic requirements. ${ }^{157}$ Those projects were

154 Huxley, "The Conservation of Wild Life", 87-88.

155 Popovic, Tourism in Eastern Africa, 14, 19.

156 Watterson, Conservation of Nature, 22.

157 See ch. 3; Terminal Report, ETH/74/014, 2. 
only possible because larger amounts of money could be redirected from development programmes such as the UNDP, Special Funds or the World Bank.

The final reports of the tourism missions all shared a deeply invasive way of looking at the countries, their people and their culture. In short, they approached the local cultures and national identities with a tourist gaze-the view of tourists on their surroundings, which is guided by a set of expectations in the tourists' minds, and objectifies people, places and cultural practices. ${ }^{158}$ Through the tourism development missions, knowledge production within the context of the development decade was furnished with a particular dimension of touristic imagination. The promotion of tourism relies on a consensual language used and comprehended between the producers and recipients of the promotional material. ${ }^{159}$ Tourism, like heritage, necessitated a discussion about people, places and events in terms that would be understood by the major audience for tourism in the Western hemisphere, and consequently shaped local culture and nature into narratives and concepts that would fit into the Western worldview. ${ }^{160}$ UNESCO and the other international actors involved were in charge of cultural production and the representation of cultural identities, providing meaning to how those cultures were seen everywhere else and acting as knowledge producers for national and cultural identities.

Like in Ethiopia, within many developing countries this imagery, and the paternalistic development ideologies behind the cultural tourism missions, were not far from the local ruling elites' perspective on the people living at sites of potential touristic interest. The Western experts' assessment of what constituted the country's most relevant history was often very similar to the idea of those internationally connected and educated elites. ${ }^{161}$

From a long-term perspective, tourism missions did indeed create a long-lasting destination value in many developing countries, insofar as they had a significant impact on the evolution of national heritage conservation and the World Heritage Programme. Through their reports the consultants established and unlocked funding for collaboration and for expert activity in the heritage sector of

158 Morgan and Pritchard, Tourism Promotion and Power, 169; John Urry, The tourist gaze: leisure and travel in contemporary societies (London: Sage, 1990), 1-3, 110-12.

159 Stuart Hall, “The Work of Representation”, in Representation: Cultural Representations and Signifying Practices, ed. Stuart Hall (London; Thousand Oaks, CA; New Delhi: SAGE, 1997), $13-24$.

160 Nash, “Tourism as a Form of Imperialism”, 45-46.

161 Keith Hollinshead, "Tourism and New Sense: Worldmaking and the Enunciative Value of Tourism", in Tourism and Postcolonialism: Contested Discourses, Identities, and Representations, ed. C. Michael Hall and Hazel Tucker (Abingdon, Oxon; New York: Routledge, 2004), 38-39. 
many countries. In particular, this contributed significantly to the success of the World Heritage Programme in its early years, as many countries could provide at least some heritage sites that would meet the elaborate scientific standards required for a World Heritage nomination. Tourism missions represented a critical mass of activities that notably fostered the successful implementation of the World Heritage Convention by providing a stock of heritage sites ready for nomination as World Heritage. These sites had been restored and conserved in collaboration with UNESCO. Without all these preceding activities in cultural tourism, owing to the development decade, there would not have been so many sites already in the UNESCO system by the time the World Heritage Programme came into being.

\section{Tourism as vehicle of heritage-making}

The increased priority on the development of tourism prompted an increase in attention from UNESCO, as it promised to provide larger budgets for projects to develop. ${ }^{162}$ Shortly after the Ethiopian Ministry of Planning announced the new orientation of the development plan as regards tourism, UNESCO's office of relations with member states (not the cultural heritage division) organised a mission to Ethiopia. The monuments, wildlife areas and scenic landscapes lacked the provisions to be visited by larger crowds or a high number of visitors over the year. In 1968, even the infrastructure of the major points of touristic interest, along the "Historic Route", was assessed to be largely insufficient and incapable of absorbing even a relatively minor growth in tourist numbers. ${ }^{163}$ Initiating this mission, similarly to previous successful missions in other countries "where important projects for conservation and development of sites and monuments [were] now under way”, were a team composed of an architect-restorer, an economist-planner and a member of the UNESCO secretariat. ${ }^{164}$ This interaction marked the beginning of the many activities involving UNESCO that would result in the consideration that Ethiopian heritage was fit to be included in the World Heritage list.

As a result of this, during the visit of UNESCO’s DG René Maheu to Ethiopia, cultural tourism was adopted as a special point into the cooperation agreement between the imperial Ethiopian government and UNESCO. The detailed explana-

162 In the letter from Belai Abbai to Malcolm Adiseshiah (footnote 553) the word tourism was circled in red.

163 Angelini and Mougin, "Proposals for the Development", 5.

164 Response letter from Malcolm Adiseshiah to Abbai, 14.2.68, UNESCO X07.21 (63) pt. iv. 
tion of the "cultural tourism" point declared that UNESCO would provide assistance in creating an inventory of monuments and works of art, as well as for the preservation and conservation of nature. ${ }^{165}$ UNESCO's heritage experts readily picked up on the assessment that tourism was crucial for Ethiopia's economic development and that the country had great potential, as tourism would provide the funds necessary for conservation. This explains why the UNESCO missions for cultural and natural heritage between 1968 and 1984 were concerned with tourism planning efforts in relation to wildlife and cultural heritage conservation.

The gravitational influence of development aid and expected tourist revenue re-structured and re-aligned the national heritage landscape of Ethiopia, whereby in addition to the economic aspect, heritage-making also served varied political agendas. Developing tourism in Ethiopia was as much motivated by economic prospects as it was by the outlook of creating a strong, world-wide iconography of success. The proponents of tourism predicted that "the time will come when the Ethiopian Tourist Organization will be proud of [...] being the sole organization to succeed in moving Ethiopia into the channels of world economy, in order to operate wherein any country must first of all be known."166

The use of symbolic images of monumental and natural heritage sites in Ethiopia is impressively visible in the first tourism campaigns and in general government representation in the years following the Italian occupation period and the subsequent years of recovery, development and modernisation. The "Historic Route" and maps of "Greater Ethiopia” were used to install a dominant historical narrative. Images of heritage were condensed into a strong iconography of national heritage, utilised to foster national identity and serve as an important tool for governance and representation. In the Ethiopian imperial state, and likewise in the following military government and under the Derg, the use of selected historic sites served to create the image of a country that had a right to its claims of power and relevance in the international order, and likewise held the promise of developing into an economically strong nation.

The international heritage experts took the increased relevance derived from the touristic initiative to their advantage, and tried to argue that only with a properly set up scientific standard of conservation, as state responsibility,

165 Aide-memoire on points of agreement reached at the inter-ministerial meeting on cooperation between the imperial Ethiopian Government and UNESCO, 31.7.1968 in: UNESCO X07.21 (63) pt. iv.

166 Ianus. Organizzazione per gli studi e le ricerche di economia applicata S. p. A., Ethiopian Tourist Development Plan, 13. 
could the development of heritage-sites into destinations reap fruitful results. They were aware that "the Ethiopian Government [was] in no better position than other governments to devote large sums of money to conservation for ethical reasons alone" 167 and that conservation in its own right would remain a lowpriority task in terms of budget allocation. In their report, Angelini and Mougin suggested a very detailed restructuring of the existing bureaucratic infrastructure of all authorities related to tourism. Realising that tourism concerned the responsibilities of nine Ministries altogether, they concluded that the ETO should be attached to the Prime Minister's office, to sit near yet outside the necessary ministries. ${ }^{168}$

Because of the economic reasoning that tourism was necessary for development, heritage-making changed status from a relatively peripheral issue in the government's responsibilities to a more central role, involving the Ministry of Planning. Tourism accelerated the process of heritage-making in Ethiopia significantly, with an emphasis on developing those aspects which were particularly relevant for connecting Ethiopian heritage to the concept of universal heritage. Angelini, in his work plan for the "Historic Route" insisted on an inventory of all heritage sites, like Howland, which was to be started in the "Historic Route" area. $^{169}$

As a matter of fact, it was only through the incentives provided by tourism that the conservation and heritage-making projects of UNESCO found an administrative counterpart in the Ethiopian government that would actualise certain projects towards implementation. After the input of all experts in the development of tourism, the "Historic Route" was given the highest priority by the Ministry of Development and Planning. ${ }^{170}$ It is important to note that the missions of Angelini and Mougin (preparation of tourism development), Angelini (the "Historic Route") as well as Gaidoni (tourism development) were not requested by the Ministry of Education or in context of the Antiquities Administration, but by the Planning Commission, which was in charge of the five-year development plans and part of the Ministry of Development and Planning. ${ }^{171}$ Tourism had turned the making of Ethiopian heritage into a development activity. As a consequence, heritage-making gained in relevance within the administration; from being the concern of only two smaller ministerial departments for cultural and natural conservation it respectively became an inter-ministerial matter. The

167 Grimwood, “Conservation of Natural Resources”, 5.

168 Angelini and Mougin, "Proposals for the Development”, 31.

169 Angelini, "The Historic Route", 13; "Recommendations", 3-5.

170 Angelini and Mougin, "Proposals for the Development", 4.

171 Letter from Belai Abbai to Malcolm Adiseshiah, 4.1.1968, UNESCO X 07.21 (63) pt. iv. 
more extensive bureaucratic procedures of heritage-making that followed, necessitated by the economic planning and facilitated by new actors such as the tourism consultants, should prove useful. In many of these tourism planning efforts, the requirements for documentation and management planning, which were particularly important to fulfil the formal criteria for World Heritage, were already partially or wholly fulfilled. 